Article

\title{
Simple synthesis of nitrogen-doped carbon spheres as a highly efficient metal-free electrocatalyst for the oxygen reduction reaction
}

\author{
Jinhui Tong a,*, Wenyan Li a, Lili Bo b, Wenhui Wang a, Yuliang Li a, Tao Li a , Qi Zhang a, Haiyan Fan c,\# \\ ${ }^{a}$ Key Laboratory of Polymer Materials of Gansu Province, Key Laboratory of Eco-Environment-Related Polymer Materials Ministry of Education, College of \\ Chemistry and Chemical Engineering, Northwest Normal University, Lanzhou 730070, Gansu, China \\ b College of Science, Gansu Agricultural University, Lanzhou 730070, Gansu, China \\ c Department of Chemistry, School of Science and Technology, Nazarbayev University, Astana 010000, Kazakhstan
}

\section{A R T I C L E I N F O}

\section{Article history:}

Received 18 April 2018

Accepted 23 April 2018

Published 5 June 2018

\section{Keywords:}

Nitrogen doping

Carbon spheres

Metal-free catalyst

Oxygen reduction reaction

\begin{abstract}
A B S T R A C T
In the present work, nitrogen-doped carbon spheres were synthesized through a simple hydrothermal treatment using glucose and melamine as inexpensive carbon and nitrogen sources, respectively. The ratio of melamine to glucose and annealing temperature were optimized. The final optimal sample exhibited a catalytic activity for the oxygen reduction reaction (ORR) that was superior than that of commercial 20\% Pt/C in $0.1 \mathrm{~mol} / \mathrm{L} \mathrm{KOH}$. It revealed an onset potential of $-22.6 \mathrm{mV}$ and a half-wave potential of $-133.6 \mathrm{mV}$ (vs. $\mathrm{Ag} / \mathrm{AgCl}$ ), which are 7.2 and $5.9 \mathrm{mV}$ more positive than those of the $20 \% \mathrm{Pt} / \mathrm{C}$ catalyst, respectively, as well as a limiting current density of $4.6 \mathrm{~mA} / \mathrm{cm}^{2}$, which is $0.2 \mathrm{~mA} / \mathrm{cm}^{2}$ higher than that of the $20 \% \mathrm{Pt} / \mathrm{C}$ catalyst. The catalyst also exhibited higher stability and superior durability against methanol than $20 \% \mathrm{Pt} / \mathrm{C}$. Moreover, ORRs on this catalyst proceed through a more effective $4 \mathrm{e}^{-}$path. The above mentioned superiority of the as-prepared catalyst makes it promising for fuel cells.
\end{abstract}

(c) 2018, Dalian Institute of Chemical Physics, Chinese Academy of Sciences. Published by Elsevier B.V. All rights reserved.

\section{Introduction}

As efficient clean energy suppliers, fuel cells have attracted increasing interest in recent years [1-4]. However, the large-scale application of fuel cells has been limited by the slow ORRs at the cathode, where highly efficient catalysts are demanded [5]. Pt catalysts have been considered among the best ORR catalysts; however, they suffer from some drawbacks such as sensitivity to current drift, CO deactivation, instability towards methanol, high cost, and limited supply of Pt [6,7].

To overcome the limitations of Pt-based catalysts, much effort has been made to identify alternatives to replace them.
Besides the development of nonprecious metal-based or precious metal alloy-based catalysts, efforts have been gradually focused on metal-free electrocatalysts [8,9], in particular, catalysts composed of heteroatom-doped carbon materials [10-12]. Carbon spheres have shown impressive surface permeability and high mechanical stability; hence, they have been extensively used in many areas such as catalysis, adsorption, drug delivery, and energy storage $[13,14]$. Lately, carbon spheres have been used as ORR catalysts $[15,16]$. However, their rather chemically inert surface and small surface area-to-volume ratio have limited their application in ORRs [16]. Diversified strategies have been adopted to modify the physical

\footnotetext{
* Corresponding author. Tel: +86-931-7970806; E-mail: jinhuitong@126.com

\# Corresponding author. Tel: +7-7172-704656; E-mail: haiyan.fan@nu.edu.kz

This work was supported by the National Natural Science Foundation of China (21363021, 51302222) and Program for Changjiang Scholars and Innovative Research Team in University (IRT15R56).

DOI: 10.1016/S1872-2067(18)63078-5 | http://www.sciencedirect.com/science/journal/18722067 | Chin. J. Catal., Vol. 39, No. 6, June 2018
} 
and/or chemical properties of the carbon spheres. Among them, doping the lattice structure of carbon with heteroatoms has turned to be the most effective method to take full advantage of the carbon sphere properties [17-20]. Doping of heteroatoms not only enhances surface adsorption ability but also increases catalytic activity and stability through the modification of the electron density distribution of carbon atoms [21]. In general, doping of nitrogen is mainly performed through three methods, including the post-processing method $[22,23]$, hard template method [24,25], and soft template method [26,27]. Most of the reported methods are complicated and multistep and, consequently, have low production efficiency. Therefore, much simpler methods are desirable for the preparation of highly effective N-doped carbon spheres using cheap and abundant raw materials.

The present work uses glucose as the carbon source and melamine as the nitrogen source to develop a nitrogen-doped carbon sphere catalyst (NCS). The ORR tests indicate that the as-prepared catalyst possesses great catalytic activity, stability, and long-term durability against methanol-induced toxicity.

\section{Experimental}

\subsection{Chemicals}

Pt/C (20 wt\% Pt on carbon black) and Nafion (5 wt\%) were brought from Alfa Aesar. Mesoporous silica (average particle size $200 \mathrm{~nm}$, specific surface area $300 \mathrm{~m}^{2} / \mathrm{g}$, pore volume 0.5 $\mathrm{cm}^{3} / \mathrm{g}$ ) was purchased from Sigma-Aldrich. All other chemicals and reagents are of analytical grade and were used as-received.

\subsection{Preparation of the catalysts}

Certain amount of glucose and melamine was dissolved in a $1.5 \% \mathrm{H}_{2} \mathrm{SO}_{4}$ solution $(10 \mathrm{~mL})$. After adding $2.0 \mathrm{~g}$ of mesoporous $\mathrm{SiO}_{2}$, the mixture was stirred for $15 \mathrm{~min}$, followed by $30 \mathrm{~min}$ sonication. After being stirred for $3 \mathrm{~h}$, the mixture was hydrothermally treated at $100{ }^{\circ} \mathrm{C}$ for $6 \mathrm{~h}$ and at $160{ }^{\circ} \mathrm{C}$ for another 6 h. The solid product was centrifuged, thoroughly washed by distilled water and ethanol, and then dried in vacuum at $100^{\circ} \mathrm{C}$. The dried sample was calcinated in a $\mathrm{N}_{2}$ atmosphere for $3 \mathrm{~h}$ at $800{ }^{\circ} \mathrm{C}$. After the heat treatment, the product was treated with $\mathrm{HF}$ solution to remove $\mathrm{SiO}_{2}$. The residual solid was collected upon centrifuging, thoroughly washed using distilled water and ethanol, and then dried in vacuum at $60{ }^{\circ} \mathrm{C}$ overnight. The finally obtained carbon sphere was labeled as $\mathrm{N}_{m} \mathrm{C}_{n} \mathrm{~S}-T$, where "S" denotes "sphere," the units of " $m$ " and " $n$ " are grams, representing the amount of melamine and glucose used, and " $T$ " refers to the annealing temperature $\left({ }^{\circ} \mathrm{C}\right)$. Three $\mathrm{N}$-doped samples were prepared and designated as $\mathrm{N}_{0.1} \mathrm{C}_{1.9} \mathrm{~S}-800, \mathrm{~N}_{0.1} \mathrm{C}_{1.9} \mathrm{~S}-900$, and $\mathrm{N}_{0.2} \mathrm{C}_{1.8} \mathrm{~S}-900$. For comparison purposes, a sample without nitrogen was also prepared and denoted as $\mathrm{C}_{2.0} \mathrm{~S}-900$.

\subsection{Characterization of the catalysts}

The power X-ray diffraction (XRD) patterns of the samples were collected on a Shimadzu XRD-6000 diffractometer with
$\mathrm{Cu} K_{\alpha}$ radiation $(\lambda=1.54178 \AA$ ) operating at the voltage of 40 $\mathrm{kV}$ and current $200 \mathrm{~mA}$. Scanning electron microscopy (SEM) images were obtained using a field-emission scanning electron microscope (JSM-6701F, FEOL) with the accelerating voltage of $5 \mathrm{kV}$. Transmission electron microscopy (TEM) images were taken on a JEM-2010 microscope operated at the accelerating voltage of $200 \mathrm{kV}$. X-ray photoelectron spectroscopy (XPS) was performed using a Thermo Fisher Scientific's K-Alpha X-ray photoelectron spectrometer. Raman spectra of the samples were obtained on a Jobin-Yvon U1000 scanning double monochromator at a wavelength of $532 \mathrm{~nm}$. The nitrogen adsorption-desorption characterization of the samples was performed on an ASAP 2020 Micromeritics instrument at $-196^{\circ} \mathrm{C}$.

\subsection{Electrochemical tests of the catalysts}

For electrochemical testing, a CHI electrochemical workstation equipped with the software Versa Studio was used. A three-electrode cell assembly including a 3-mm glass carbon electrode or rotating disk electrode (RDE) as the working electrode, $\mathrm{Ag} / \mathrm{AgCl}$ (in $3 \mathrm{~mol} / \mathrm{L} \mathrm{KCl}$ ) as the reference electrode, and a graphite rod as the counter electrode was used for the linear sweep voltammetry (LSV) tests. Three milligrams of the catalyst were dispersed in $0.5 \mathrm{~mL}$ of ethanol containing $10 \mu \mathrm{L}$ of a Nafion solution (5 wt\%), and the mixture was sonicated for more than $30 \mathrm{~min}$. Afterwards, $3 \mu \mathrm{L}$ of the above solution were dropped onto the surface of a well-polished working electrode, and the electrode was dried at room temperature. The LSV tests were conducted in the potential range 0.2 to $-0.8 \mathrm{~V}$ versus $\mathrm{Ag} / \mathrm{AgCl}$ electrode at a scan rate of $10 \mathrm{mV} / \mathrm{s}$ in an oxygen-saturated $0.1 \mathrm{~mol} / \mathrm{L} \mathrm{KOH}$ at room temperature. The number of transferred electrons $(n)$ and kinetic current density $\left(U_{k}\right)$ were calculated according to the well-known Koutecky-Levich equation:

$$
\begin{gathered}
1 / J=1 / J_{\mathrm{L}}+1 / J_{\mathrm{K}}=1 /\left(\mathrm{B} \omega^{1 / 2}\right)+1 / J_{\mathrm{k}} \\
B=0.2 n \mathrm{FA} v^{-1 / 6} c\left(\mathrm{O}_{2}\right) D\left(\mathrm{O}_{2}\right)
\end{gathered}
$$

where $n$ indicates the number of transferred electrons; F, Faraday constant $(96485 \mathrm{C} / \mathrm{mol}) ; c\left(\mathrm{O}_{2}\right)$, the bulk concentration of $\mathrm{O}_{2}\left(1.2 \times 10^{-6} \mathrm{~mol} / \mathrm{cm}^{3}\right)$; and $v$, the kinematic viscosity of the electrolyte $\left(0.01 \mathrm{~cm}^{2} / \mathrm{s}\right)$.

\section{Results and discussion}

\subsection{Characterization of the catalysts}

The XRD patterns of the as-prepared catalysts are shown in Fig. 1 . The broad diffraction peak at $2 \theta \approx 22.5^{\circ}$ and $44.5^{\circ}$ can be attributed to the (002) and (101) planes of graphitic carbon, respectively [28]. No other phases were detected in the samples.

Fig. 2 shows the Raman spectra of the samples. As can be seen, all the samples display two Raman scattering bands, a D band at $1350 \mathrm{~cm}^{-1}$ and a G band at $1600 \mathrm{~cm}^{-1}$, of which the D band represents the degree of disorder and the defects of the graphite structure, and the $\mathrm{G}$ band reflects the degree of graphitization. Therefore, the relative intensity ratio between the $D$ and $\mathrm{G}$ bands $\left(\mathrm{I}_{\mathrm{D}} / I_{\mathrm{G}}\right)$ is a good measure of the degree of defects 


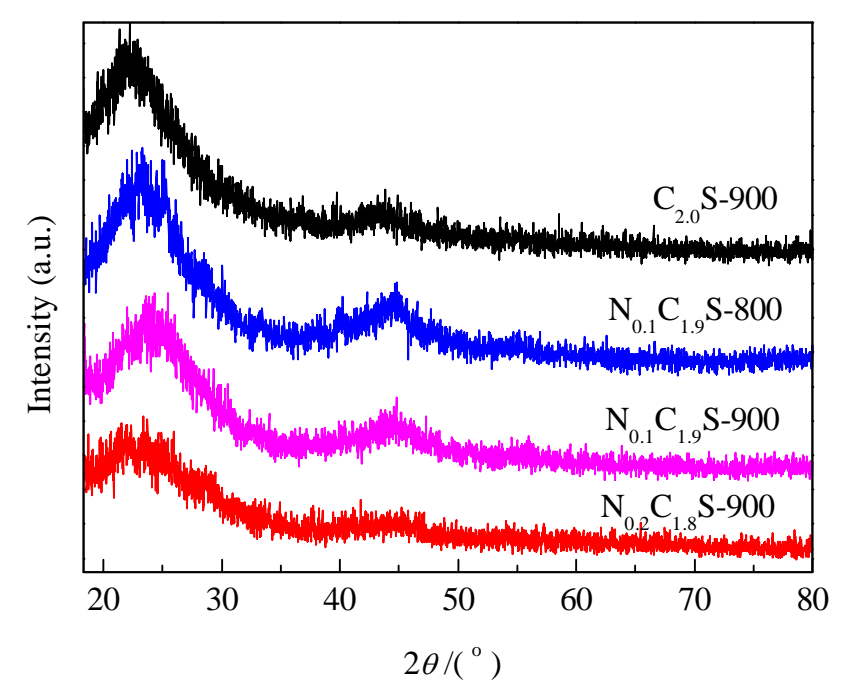

Fig. 1. XRD patterns of the samples.

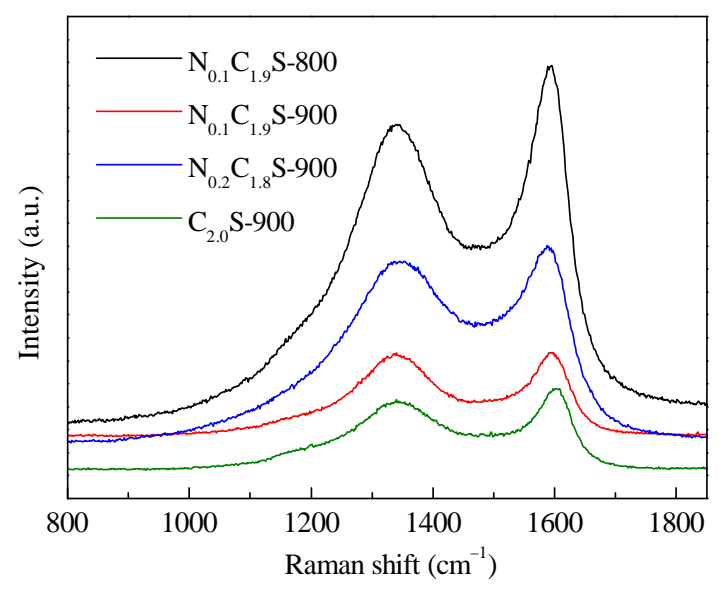

Fig. 2. Raman spectra of the samples.

or graphitization. The values of $I_{\mathrm{D}} / I_{\mathrm{G}}$ for $\mathrm{C}_{2.0} \mathrm{~S}-800, \mathrm{~N}_{0.1} \mathrm{C}_{1.9} \mathrm{~S}-800$, $\mathrm{N}_{0.1} \mathrm{C}_{1.9} \mathrm{~S}-900$, and $\mathrm{N}_{0.2} \mathrm{C}_{1.8} \mathrm{~S}-900$ are $0.91,0.86,1.00$, and 0.94 , respectively. Obviously, the $\mathrm{N}_{0.1} \mathrm{C}_{1.9} \mathrm{~S}-900$ sample has the highest $I_{\mathrm{D}} / I_{\mathrm{G}}$ value, indicating abundant structural defects and a relatively low degree of graphitization. This large number of structural defects can increase the number of active sites for the carbon-based catalysts.

Representative SEM and TEM images of the samples (Fig. 3) show that the as-prepared samples exhibit spheres with diameters ranging from 0.2 to $1.5 \mu \mathrm{m}$, and most of the spheres show diameters in the range $500-700 \mathrm{~nm}$. The surfaces of the spheres of the $\mathrm{N}$-absent sample, $\mathrm{C}_{2.0} \mathrm{~S}-900$ (Fig. 3(a)), are more glabrate than those of the $\mathrm{N}$-doped samples, $\mathrm{N}_{0.1} \mathrm{C}_{1.9} \mathrm{~S}-800$ (Fig. 3(b)) and $\mathrm{N}_{0.1} \mathrm{C}_{1.9} \mathrm{~S}-900$ (Fig. 3(c)), in which more carbon nanoparticles adhere to the carbon spheres. By comparing the SEM images of the $\mathrm{N}_{0.1} \mathrm{C}_{1.9} \mathrm{~S}-800$ and $\mathrm{N}_{0.1} \mathrm{C}_{1.9} \mathrm{~S}-900$ samples, it can also be seen that higher calcination temperatures lead to larger carbon spheres. As a result, the average diameter of the $\mathrm{N}_{0.1} \mathrm{C}_{1.9} \mathrm{~S}-800$ sample is around $150 \mathrm{~nm}$ shorter than that of the $\mathrm{N}_{0.1} \mathrm{C}_{1.9} \mathrm{~S}-900$ sample. The SEM and TEM images of the broken sample (inset in Fig. 3(c)) show that the carbon spheres are
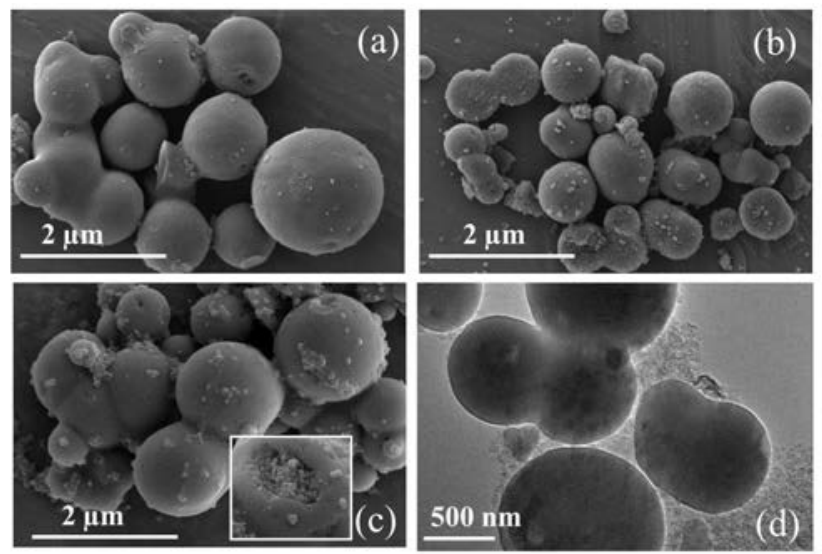

Fig. 3. SEM images of $\mathrm{C}_{2.0} \mathrm{~S}-900$ (a), $\mathrm{N}_{0.1} \mathrm{C}_{1.9} \mathrm{~S}-800$ (b), and $\mathrm{N}_{0.1} \mathrm{C}_{1.9} \mathrm{~S}-900$ (c), and TEM image of $\mathrm{N}_{0.1} \mathrm{C}_{1.9} \mathrm{~S}-900$ (d).

fluffy and porous (Fig. 3(d)). The energy dispersive X-ray spectral (EDS) mapping of $\mathrm{N}_{0.1} \mathrm{C}_{1.9} \mathrm{~S}-900$ based on the selected area of the SEM image (Fig. 4(a)) shows that the elements $\mathrm{C}, \mathrm{N}$, and 0 are evenly distributed in the samples (Fig. 4(b)-(d)).

XPS analyses were performed to determine the atomic content and chemical identities of $\mathrm{C}$ and $\mathrm{N}$. The atomic content of the samples, as determined by XPS, is summarized in Table 1. It can be seen that the relative content of nitrogen increased with the increase of added melamine, while it decreased with the increase in the calcination temperature, because the $\mathrm{C}-\mathrm{N}$ bonds break at higher temperatures. The high-resolution $\mathrm{C} 1 s$ and $\mathrm{N}$ $1 s$ spectra of the $\mathrm{N}_{0.1} \mathrm{C}_{1.9} \mathrm{~S}-900$ sample are shown in Fig. 5, while those of the other samples are shown in Fig. S1 and S2. The C $1 s$ spectra of all the samples can be deconvoluted into two peaks ascribed to the $\mathrm{C}$ in graphitic $\mathrm{C}-\mathrm{C}(284.7 \mathrm{eV})$ and $\mathrm{C}-\mathrm{N}$ bonds $(285.8 \mathrm{eV})$. The high-resolution XPS N $1 s$ patterns of the samples can be deconvoluted into three peaks attributed to pyri-
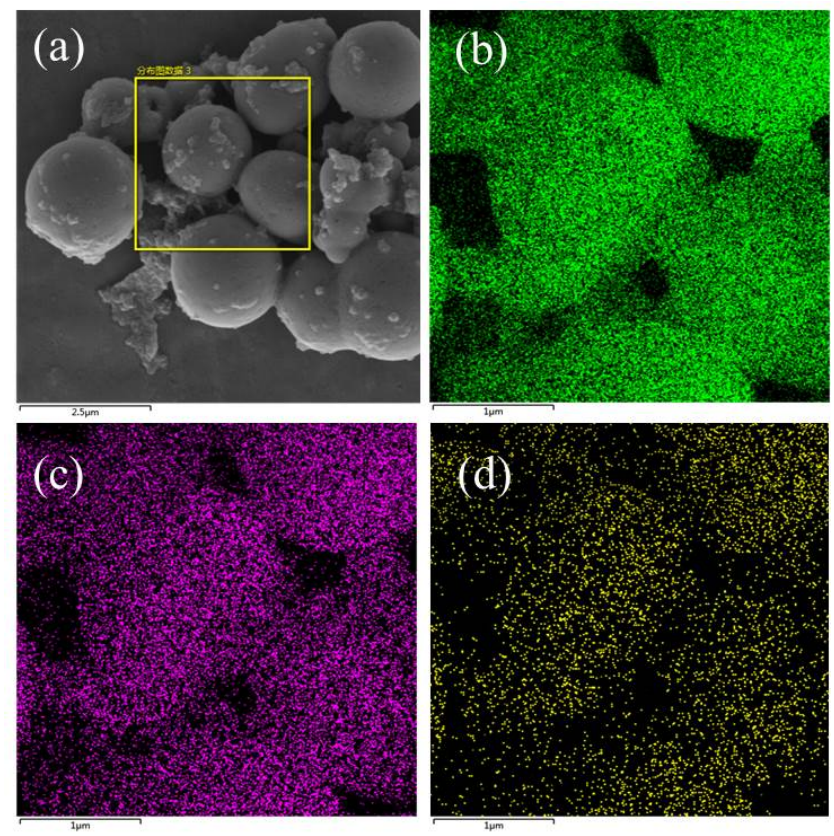

Fig. 4. Element mapping of C (b), N (c), and $\mathrm{O}(\mathrm{d})$ based on the selected region of the SEM image (a) of the $\mathrm{N}_{0.1} \mathrm{C}_{1.9} \mathrm{~S}-900$ catalyst. 
Table 1

Atomic content (at\%) of the different samples, as determined by XPS analysis.

\begin{tabular}{lccc}
\hline Sample & C (at\%) & N (at\%) & O (at\%) \\
\hline $\mathrm{N}_{0.1} \mathrm{C}_{1.9} \mathrm{~S}-800$ & 90.88 & 1.99 & 7.13 \\
$\mathrm{~N}_{0.1} \mathrm{C}_{1.9} \mathrm{~S}-900$ & 94.71 & 0.99 & 4.30 \\
$\mathrm{~N}_{0.2} \mathrm{C}_{1.8} \mathrm{~S}-900$ & 93.84 & 2.49 & 3.67 \\
\hline
\end{tabular}
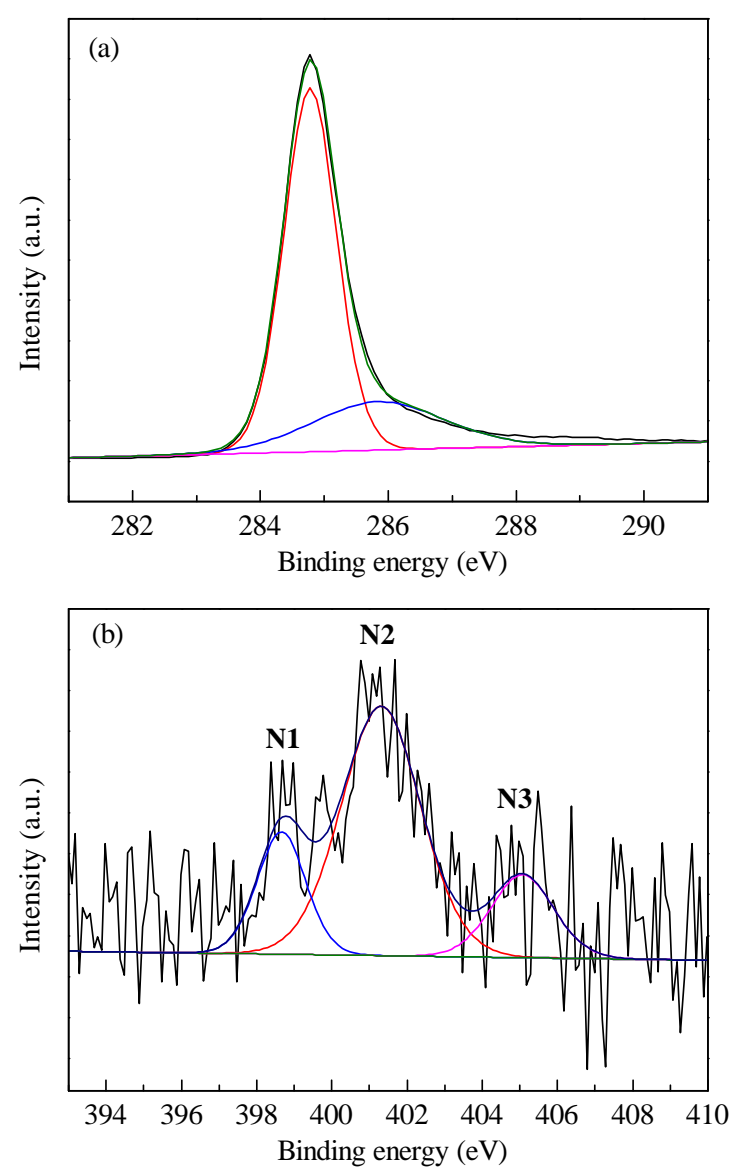

Fig. 5. High-resolution XPS spectra of $\mathrm{C} 1 s$ (a) and $\mathrm{N} 1 s$ (b) for the $\mathrm{N}_{0.1} \mathrm{C}_{1.9} \mathrm{~S}-900$ sample.

dinic nitrogen $\left(\mathrm{N}_{1}, 398.5 \pm 0.2 \mathrm{eV}\right)$, graphitic nitrogen $\left(\mathrm{N}_{2}, 401.2\right.$ $\pm 0.2 \mathrm{eV})$, and $\mathrm{N}$-oxides $\left(\mathrm{N}_{3}, 405.2 \pm 0.2 \mathrm{eV}\right)$. The relative atomic content of the different $\mathrm{C}$ and $\mathrm{N}$ species in the samples are listed in Table 2 and 3, respectively. It turns out that at high annealing temperatures, the graphitic $\mathrm{C}$ content increases while the content of $\mathrm{C}$ in the $\mathrm{C}-\mathrm{N}$ bonds decreases, implying that a high annealing temperature favors the graphitization of the samples instead of the formation of $\mathrm{C}-\mathrm{N}$ bonds. Regarding the $\mathrm{N}$ content, it can be seen from Table 3 that the $\mathrm{N}_{0.1} \mathrm{C}_{1.9} \mathrm{~S}-900$ sample contained the highest amount of graphitic nitrogen (64.03\%), while the $\mathrm{N}_{0.2} \mathrm{C}_{1.8} \mathrm{~S}-900$ sample had the highest pyridinic nitrogen content (33.10\%). It is generally accepted that graphitic nitrogen produces the most active catalytic centers because the doped nitrogen can potentially cause the electron density donation from the bonding orbitals of the graphitic carbon frame to the antibonding orbital of the oxygen, and thereby enhance the catalytic effect $[28,29]$.
Table 2

Atomic content of the different $\mathrm{C}$ species in the samples.

\begin{tabular}{lcc}
\hline Sample & $\begin{array}{c}\text { C in graphitic C-C } \\
\text { (C } 1 s \text { ca. 284.7 eV) }\end{array}$ & $\begin{array}{c}\text { C in C-N } \\
(C 1 s \text { ca. 285.8 eV })\end{array}$ \\
\hline $\mathrm{N}_{0.1} \mathrm{C}_{1.9} \mathrm{~S}-800$ & 72.37 & 27.63 \\
$\mathrm{~N}_{0.1} \mathrm{C}_{1.9} \mathrm{~S}-900$ & 75.09 & 24.91 \\
$\mathrm{~N}_{0.2} \mathrm{C}_{1.8} \mathrm{~S}-900$ & 76.03 & 23.97 \\
\hline
\end{tabular}

Table 3

Atomic content of the different $\mathrm{N}$ species in the samples.

\begin{tabular}{lccc}
\hline Sample & $\begin{array}{c}\text { Pyridinic N } \\
(\mathrm{N} 1 s \text { ca. 398.5 eV) }\end{array}$ & $\begin{array}{c}\text { Graphitic-type N } \\
(\mathrm{N} 1 s \text { ca. } 401.2 \mathrm{eV})\end{array}$ & $\begin{array}{c}\mathrm{N} \text { in N-oxide } \\
(\mathrm{N} 1 s \text { ca. } 405.0 \mathrm{eV})\end{array}$ \\
\hline $\mathrm{N}_{0.1} \mathrm{C}_{1.9} \mathrm{~S}-800$ & 29.55 & 46.87 & 23.59 \\
$\mathrm{~N}_{0.1} \mathrm{C}_{1.9} \mathrm{~S}-900$ & 19.21 & 64.03 & 16.76 \\
$\mathrm{~N}_{0.2} \mathrm{C}_{1.8} \mathrm{~S}-900$ & 33.10 & 49.95 & 16.94 \\
\hline
\end{tabular}

The $\mathrm{N}_{2}$ adsorption-desorption isotherms and pore size distribution plots (inset) for the $\mathrm{N}_{0.1} \mathrm{C}_{1.9} \mathrm{~S}-900$ catalyst are displayed in Fig. 6, while those for the other samples are shown in Fig. S3. The Brunauer-Emmett-Teller (BET) surface areas and pore volumes of the samples are listed in Table 4 . All the catalysts exhibit typical type II $\mathrm{N}_{2}$ absorption-desorption isotherms, with a type IV hysteresis loop, which is indicative of samples with mesoporous structures. This is also confirmed by the pore size distribution plots of the samples. As a result, the mesoporous portion of the BET surface area and pore volume occupies more than $60 \%$ of the total (Table 4). Table 4 also shows that the BET surface area of the samples increases with increasing calcination temperature and melamine amount because a larger portion of the gas is released during the annealing process.

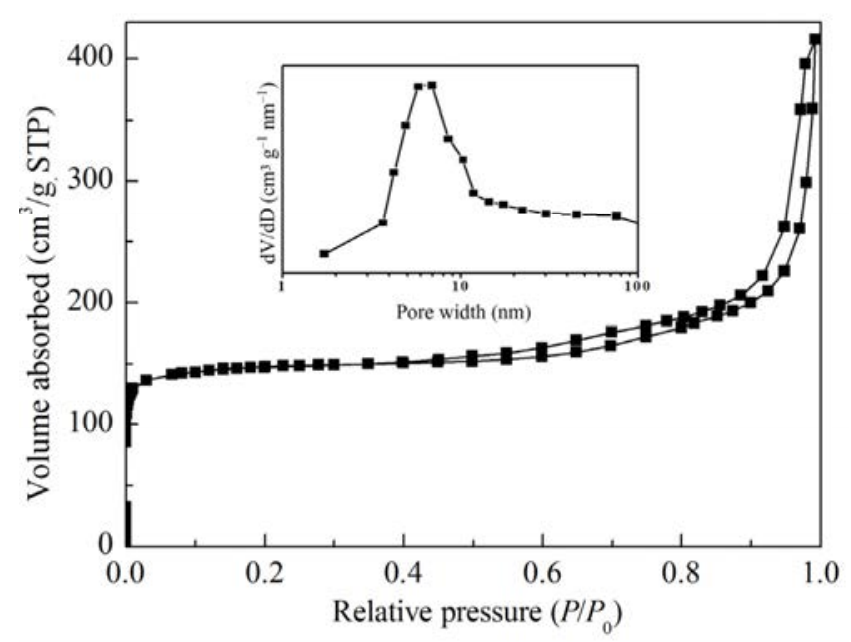

Fig. 6. $\mathrm{N}_{2}$ adsorption-desorption isotherms and pore size distribution plot (inset) of the $\mathrm{N}_{0.1} \mathrm{C}_{1.9} \mathrm{~S}-900$ sample.

Table 4

$\mathrm{N}_{2}$ adsorption-desorption characterization of the catalysts.

\begin{tabular}{llrrrr}
\hline Sample & $\mathrm{C}_{2.0} \mathrm{~S}-900$ & $\mathrm{~N}_{0.1} \mathrm{C}_{1.9} \mathrm{~S}-800$ & $\mathrm{~N}_{0.1} \mathrm{C}_{1.9} \mathrm{~S}-900$ & $\mathrm{~N}_{0.2} \mathrm{C}_{1.8} \mathrm{~S}-900$ \\
\hline$A_{\text {BET }}$ & Total & 279 & 184 & 446 & 469 \\
$\left(\mathrm{~m}^{2} / \mathrm{g}\right)$ & microporous & 71 & 11 & 77 & 55 \\
& mesoporous & 208 & 173 & 369 & 414 \\
Pore & Total & 0.41 & 0.26 & 0.61 & 0.64 \\
volume & microporous & 0.09 & 0.10 & 0.22 & 0.19 \\
$\left(\mathrm{~cm}^{3} / \mathrm{g}\right)$ & mesoporous & 0.32 & 0.16 & 0.39 & 0.45 \\
\hline
\end{tabular}


In particular, the BET surface areas were as high as 446 and $469 \mathrm{~m}^{2} / \mathrm{g}$ for the $\mathrm{N}_{0.1} \mathrm{C}_{1.9} \mathrm{~S}-900$ and $\mathrm{N}_{0.2} \mathrm{C}_{1.8} \mathrm{~S}-900$ samples, respectively.

\subsection{Electrochemical tests}

The catalytic performances of the as-prepared and commercial $20 \% \mathrm{Pt} / \mathrm{C}$ catalysts towards ORR were evaluated by the LSV method. The LSV curves are shown in Fig. 7(a), and the corresponding onset potential, half-wave potential, and limiting current density are listed in Table 5 . As can be seen, the catalytic activity increases in the order $\mathrm{N}_{0.1} \mathrm{C}_{1.9} \mathrm{~S}-800<\mathrm{C}_{2.0} \mathrm{~S}-900<$ $\mathrm{N}_{0.2} \mathrm{C}_{1.8} \mathrm{~S}-900<\mathrm{N}_{0.1} \mathrm{C}_{1.9} \mathrm{~S}-900$ with respect to the onset potential. It follows the same trend as the $I_{\mathrm{D}} / I_{\mathrm{G}}$ ratio and the content of graphitic $\mathrm{C}$ and $\mathrm{N}$, which also increase in the aforementioned order. These results confirm that the structural defects and content of graphitic $\mathrm{C}$ and $\mathrm{N}$ are of key importance for improving the catalytic activity of the sample [29]. It is generally accepted that graphitic nitrogen is one of the most active sites for the ORR because it can potentially promote the electron density donation from the bonding orbitals of carbon to the antibonding orbital of oxygen and thereby enhance the catalytic effect [29-31]. In particular, the $\mathrm{N}_{0.1} \mathrm{C}_{1.9} \mathrm{~S}-900$ sample exhibited the lowest onset potential $(-22.6 \mathrm{mV})$, which is even $7.2 \mathrm{mV}$ higher than that of Pt/C (20\%).
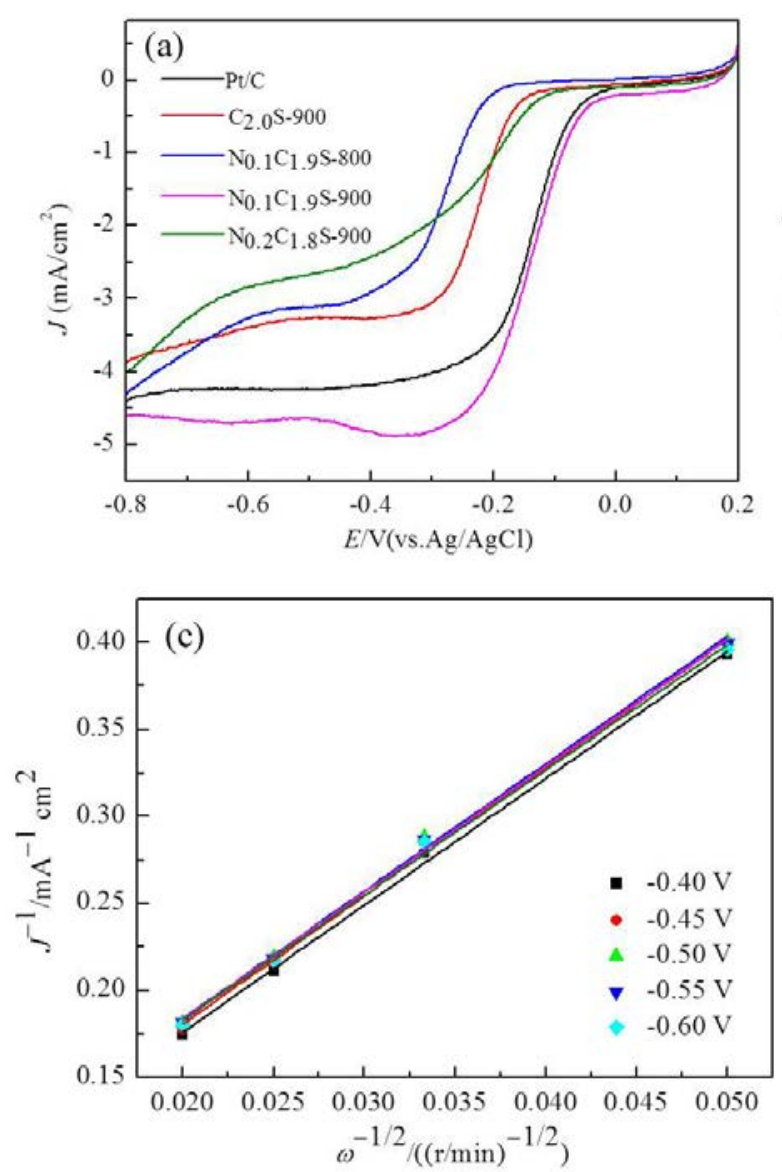

Table 5

Comparison of the catalytic activities of $20 \% \mathrm{Pt} / \mathrm{C}$ and the as-prepared samples towards the ORR.

\begin{tabular}{lccc}
\hline Sample & $\begin{array}{c}\text { Onset potential } \\
\text { (mV vs. Ag/AgCl) }\end{array}$ & $\begin{array}{c}\text { Half-wave potential } \\
\text { (mV vs. } \mathrm{Ag} / \mathrm{AgCl})\end{array}$ & $\begin{array}{c}\text { Limiting current } \\
\text { density }\left(\mathrm{mA} / \mathrm{cm}^{2}\right)\end{array}$ \\
\hline $\mathrm{Pt} / \mathrm{C}(20 \%)$ & -29.8 & -139.5 & 4.4 \\
$\mathrm{C}_{2.0} \mathrm{~S}-900$ & -155.3 & -230.1 & 3.9 \\
$\mathrm{~N}_{0.1} \mathrm{C}_{1.9} \mathrm{~S}-800$ & -205.7 & -306.0 & 4.3 \\
$\mathrm{~N}_{0.1} \mathrm{C}_{1.9} \mathrm{~S}-900$ & -22.6 & -133.6 & 4.6 \\
$\mathrm{~N}_{0.2} \mathrm{C}_{1.8} \mathrm{~S}-900$ & -104.8 & -316.7 & 2.8 \\
\hline
\end{tabular}

In order to further study the kinetics of the ORR catalyzed by $\mathrm{N}_{0.1} \mathrm{C}_{1.9} \mathrm{~S}-900$, the LSV curves were obtained at different rotation speeds, from 400 to $2500 \mathrm{r} / \mathrm{min}$, at a scan rate of 10 $\mathrm{mV} / \mathrm{s}$ (Fig. 7(b)). Fig. 7 shows that the limiting current density increases with the increase in the rotation speed from 400 to $2500 \mathrm{r} / \mathrm{min}$, because the oxygen flux to the electrode surface is enhanced at high rotation speeds. A relatively wide plateau is observed for all the rotation speeds in the range -0.3 to $-0.8 \mathrm{~V}$, indicating that the catalyst is evenly distributed on the surface of the electrode. The linear relationship between $J^{-1}$ and $\omega^{-1 / 2}$ (Fig. 7(c)) suggests first-order reaction kinetics with respect to the concentration of dissolved oxygen. Fig. 7(d) presents the number of transferred electrons $(n)$ under different potential values according to the Koutecky-Levich (K-L) equation
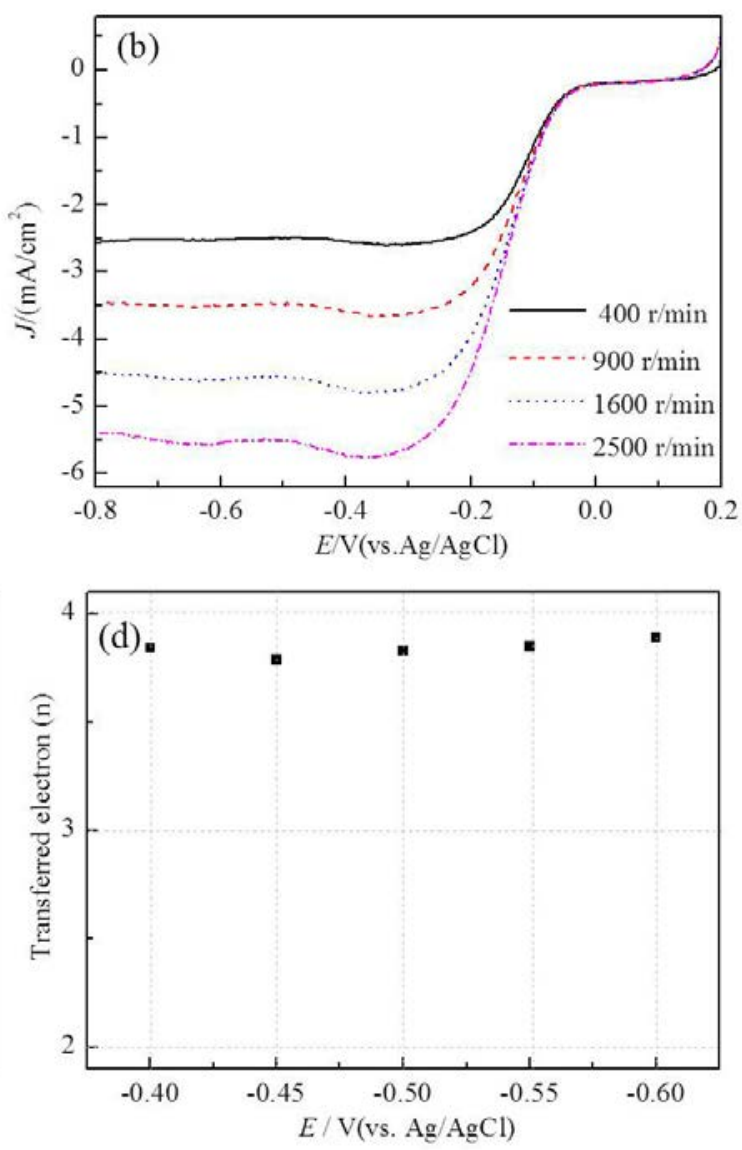

Fig. 7. (a) Polarization curves of the catalysts in an $\mathrm{O}_{2}$-saturated $0.1 \mathrm{~mol} / \mathrm{L} \mathrm{KOH}$ solution at a rotation speed of $1600 \mathrm{r} / \mathrm{min}$; (b) LSV curves of $\mathrm{N}_{0.1} \mathrm{C}_{1.9} \mathrm{~S}-900$ at different rotation speeds; (c) Koutecky-Levich plots for $\mathrm{N}_{0.1} \mathrm{C}_{1.9} \mathrm{~S}-900$ at different potentials, and (d) dependence of the number of transferred electrons, $n$, on the different potentials used in (c). 

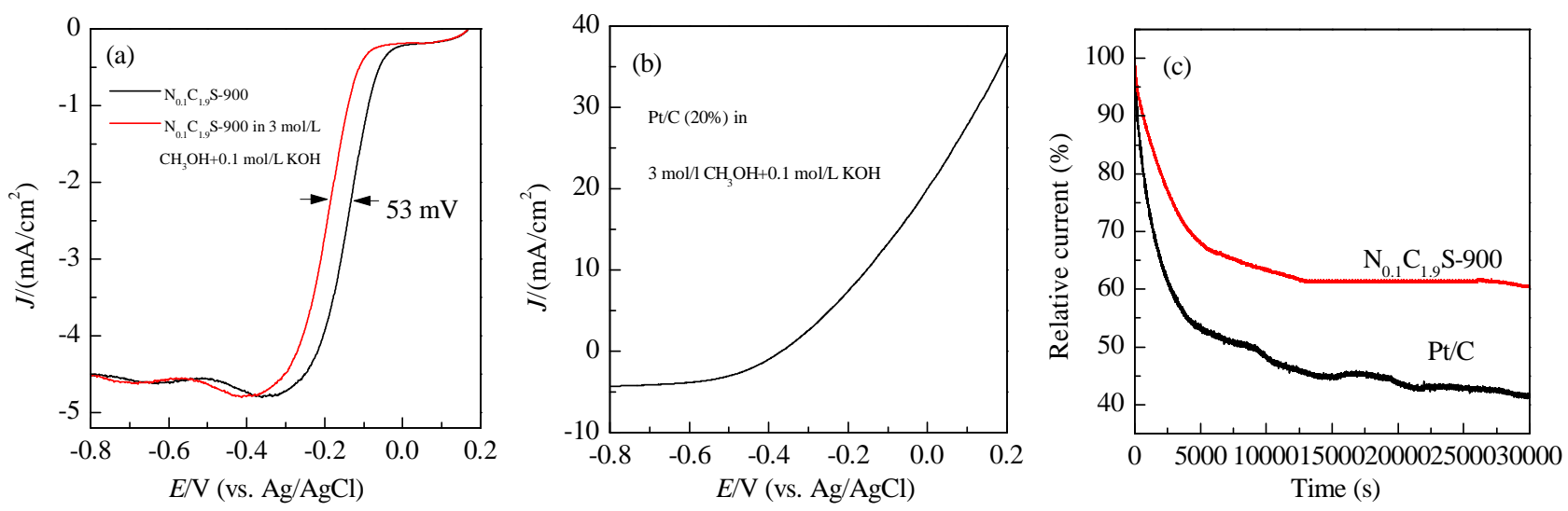

Fig. 8. Tests of resistance to methanol for $\mathrm{N}_{0.1} \mathrm{C}_{1.9} \mathrm{~S}-900$ (a) and $20 \% \mathrm{Pt} / \mathrm{C}$ (b) at $1600 \mathrm{r} / \mathrm{min}$ at the scan rate of $10 \mathrm{mV} / \mathrm{s}$; (c) The current-time curves of $20 \% \mathrm{Pt} / \mathrm{C}$ and $\mathrm{N}_{0.1} \mathrm{C}_{1.9} \mathrm{~S}-900$ at $-0.3 \mathrm{~V}$ (vs. $\mathrm{Ag} / \mathrm{AgCl}$ ) in an $\mathrm{O}_{2}$-saturated $0.1 \mathrm{~mol} / \mathrm{L} \mathrm{KOH}$ solution for $30,000 \mathrm{~s}$ at $1600 \mathrm{r} / \mathrm{min}$.

$[32,33]$. The average number of transferred electrons, $n$, is found to be 3.84 in the potential range -0.40 to $-0.60 \mathrm{~V}$, indicating approximately a $4 \mathrm{e}^{-}$ORR pathway. Generally, the $4 \mathrm{e}^{-}$ process is considered to be more efficient for the ORR [7].

In the methanol-based proton exchange membrane fuel cell, methanol can permeate through the membrane to the cathode, which can affect the efficiency of the cathodic catalyst [34,35]. Therefore, the resistance to corrosion caused by methanol crossover is a serious issue that needs to be considered in direct methanol fuel cells. The durability of $\mathrm{N}_{0.1} \mathrm{C}_{1.9} \mathrm{~S}-900$ toward methanol was tested in $\mathrm{O}_{2}$-saturated $3 \mathrm{~mol} / \mathrm{L} \mathrm{CH}_{3} \mathrm{OH}$ in a 0.1 mol/L KOH solution. Fig. 8(a) shows that a negative shift of only $53 \mathrm{mV}$ was observed in the half-wave potential after $\mathrm{CH}_{3} \mathrm{OH}$ addition without any decrease in the limiting current density. Comparatively, methanol was oxidized in the case of the commercial $20 \% \mathrm{Pt} / \mathrm{C}$ catalyst under the same conditions (Fig. 8(b)).

Long-term stability is another important indicator for the ORR catalysts [36,37]. The stability of the $\mathrm{N}_{0.1} \mathrm{C}_{1.9} \mathrm{~S}-900$ and $20 \% \mathrm{Pt} / \mathrm{C}$ catalysts was evaluated by measuring the current-time curve, as shown in Fig. 8(c), in an $\mathrm{O}_{2}$-saturated 0.1 mol/L KOH solution. After 30000 s, only a $39.7 \%$ decay in the current density was observed for $\mathrm{N}_{0.1} \mathrm{C}_{1.9} \mathrm{~S}-900$, while the current density for $20 \% \mathrm{Pt} / \mathrm{C}$ decayed $58.5 \%$.

The above results indicate that $\mathrm{N}_{0.1} \mathrm{C}_{1.9} \mathrm{~S}-900$ has higher stability and resistance to methanol than commercial 20\% Pt/C in alkaline conditions.

\section{Conclusions}

In the present work, we use glucose as the carbon source and melamine as the nitrogen source to synthesize nitrogen-doped biocarbon spheres through a simple hydrothermal treatment. The optimized doping of nitrogen along with an appropriate annealing temperature leads to an increase in the amount of graphitic carbon and nitrogen, which play a key role in improving the ORR catalytic activity of the sample. The optimized catalyst $\left(\mathrm{N}_{0.1} \mathrm{C}_{1.9} \mathrm{~S}-900\right)$ exhibits a better catalytic performance, higher stability, and methanol tolerance than the commercial $20 \% \mathrm{Pt} / \mathrm{C}$ catalyst. The ORRs on $\mathrm{N}_{0.1} \mathrm{C}_{1.9} \mathrm{~S}-900$ pro- ceed through a more effective $4 \mathrm{e}^{-}$pathway; this catalyst is a promising alternative to the precious metal-based catalysts.

\section{References}

[1] G. Wu, K. L. More, C. M. Johnston, P. Zelenay, Science, 2011, 332,443-447.

[2] M. Lefevre, E. Proietti, F. Jaouen, J. P. Dodelet, Science, 2009, 324, 71-74.

[3] Y. Liang, Y. Li, H. Wang, J. Zhou, J. Wang, T. Regier, H. Dai, Nat. Mater., 2011, 10, 780-786.

[4] H. T. Chung, J. H. Won, P. Zelenay, Nature Commun., 2013, 4, 1-5.

[5] F. Jaouen, E. Proietti, M. Lefevre, R. Chenitz, J. P. Dodelet, G. Wu, H. T. Chung, C. M. Johnston, P. Zelenay, Energy \& Environ. Sci., 2011, 4, 114-130.

[6] K. P. Gong, F. Du, Z. H. Xia, M. Durstock, L. M. Dai, Science, 2009, $323,760-764$.

[7] M. Winter, R. J. Brodd, Chem. Rev., 2004, 104, 4245-4269.

[8] Y. Z. Bai, B. L. Yi, J. Li, S. F. Jiang, H. J. Zhang, Z. G. Shao, Y. J. Song, Chin. J. Catal., 2016, 37, 1127-1133.

[9] J. F. Kong, W. L. Cheng, Chin. J. Catal., 2017, 38, 951-69.

[10] B. Wang, J. Power Sources, 2005, 152, 1-15.

[11] R. F. Wang, T. B. Zhou, H. Li, H. Wang, H. Q. Feng, J. Goh, S. Ji, J. Power Sources, 2014, 261, 238-244.

[12] S. Y. Wang, D. S. Yu, L. M. Dai, J. Am. Chem. Soc., 2011, 133, 5182-5185.

[13] J. Liu, S. Z. Qiao, H. Liu, J. Chen, A. Orpe, D. Y. Zhao, G. Q. Lu, Angew. Chem. Int. Ed., 2011, 50, 5947-5951.

[14] Y. Fang, D. Gu, Y. Zou, Z. X. Wu, F. Y. Li, R. C. Che, Y. H. Deng, B. Tu, D. Y. Zhao, Angew. Chem. Int. Ed., 2010, 49, 7987-7991.

[15] D. G. Gu, R. G. Ma, Y. Zhou, F. F. Wang, K. Yan, Q. A. Liu, J. C. Wang, ACS Sustainable Chem. Eng., 2017, 5, 11105-11116.

[16] S. Mezzavilla, C. Baldizzone, K. J. J. Mayrhofer, F. Schuth, ACS Appl. Mater. Interfaces, 2015, 7, 12914-12922.

[17] J. Wei, Y. Liang, X. Y. Zhang, G. P. Simon, D. Y. Zhao, J. Zhang, S. P. Jiang, H. T. Wang, Nanoscale, 2015, 7, 6247-6254.

[18] M. H. Naveen, K. Shim, M. S. A. Hossain, J. H. Kim, Y. B. Shim, $A d v$. Energy Mater., 2017, 7, 1602002.

[19] T. S. Zhou, Y. Zhou, R. G. Ma, Z. Z. Zhou, G. H. Liu, Q. Liu, Y. F. Zhu, J. C. Wang, Carbon, 2017, 114, 177-186.

[20] J. W. Xiao, C. Zhao, C. C. Hu, J. B. Xi, S. Wang, J. Power Sources, 2017, 348, 183-192.

[21] K. N. Wood, R. O'Hayre, S. Pylypenko, Energy \& Environ. Sci., 2014, 7,1212-1249. 


\section{Graphical Abstract}

Chin. J. Catal., 2018, 39: 1138-1145 doi: 10.1016/S1872-2067(18)63078-5

\section{Simple synthesis of nitrogen-doped carbon spheres as a highly efficient metal-free electrocatalyst for the oxygen reduction reaction}

Jinhui Tong *, Wenyan Li, Lili Bo, Wenhui Wang, Yuliang Li, Tao Li, Qi Zhang, Haiyan Fan *

Northwest Normal University, China; Gansu Agricultural University, China; Nazarbayev University, Kazakhstan

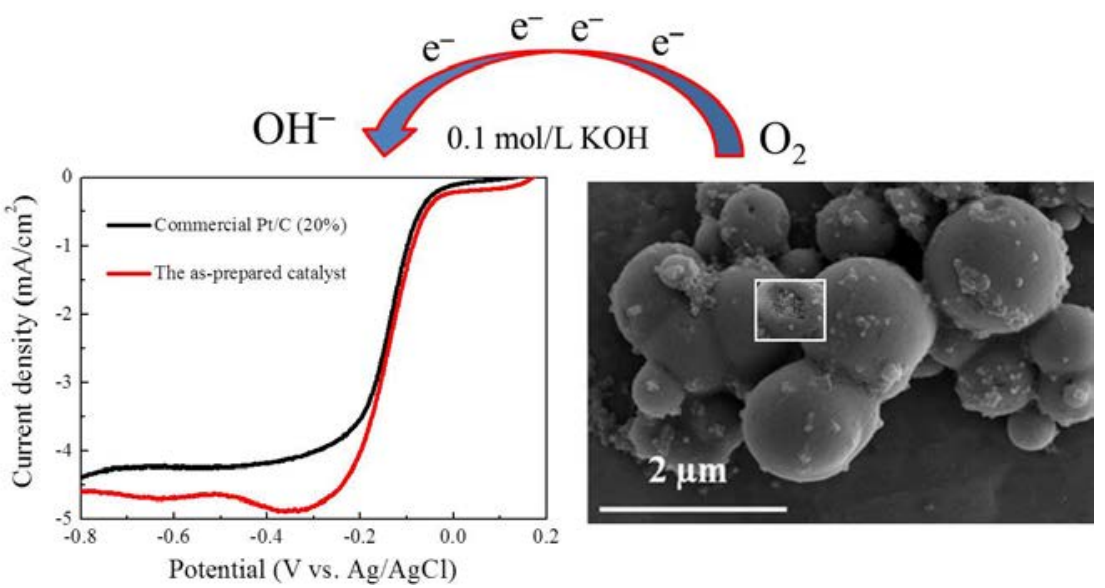

Porous N-doped carbon spheres were simply synthesized using inexpensive raw materials. The optimal sample exhibited a more effective ORR catalytic activity than commercial $20 \% \mathrm{Pt} / \mathrm{C}$ in $0.1 \mathrm{~mol} / \mathrm{L} \mathrm{KOH}$.

[22] X. Q. Wang, J. S. Lee, Q. Zhu, J. Liu, Y. Wang, S. Dai, Chem. Mater., 2010, 22, 2178-2180.

[23] X. L. Yang, W. J. Zou, Y. H. Su, Y. H. Zhu, H. L. Jiang, J. H. Shen, C. Z. Li, J. Power Sources, 2014, 266, 36-42.

[24] Q. Shi, R. Y. Zhang, Y. Y. Lv, Y. H. Deng, A. A. Elzatahrya, D. Y. Zhao, Carbon, 2015, 84, 335-346.

[25] H. Chang, S. H. Joo, C. Pak, J. Mater. Chem., 2007, 17, 3078-3088.

[26] J. Wang, H. Y. Liu, J. Y. Diao, X. M. Gu, H. H. Wang, J. F. Rong, B. N. Zong, D. S. Su, J. Mater. Chem. A, 2015, 3, 2305-2313.

[27] J. Yu, M. Y. Guo, F. Muhammad, A. F. Wang, F. Zhang, Q. Li, G. S. Zhu, Carbon, 2014, 69, 502-514.

[28] L. J. Zhang, X. Y. Wang, R. H. Wang, M. C. Hong, Chem. Mater., 2015, 27, 7610-7618.

[29] Y. H. Su, H. L. Jiang, H. Y. Zhu, X. L. Yang, J. H. Shen, W. J. Zou, J. D. Chen, C. Z. Li, J. Mater. Chem. A, 2014, 2, 7281-7287.

[30] H. Niwa, K. Horiba, Y. Harada, M. Oshima, T. Ikeda, K. Terakura, J. I.
Ozaki, S. Miyata, J. Power Sources, 2009, 187, 93-97.

[31] B. Zheng, J. Wang, F. B. Wang, X. H. Xia, Electrochem. Commun., 2013, 28, 24-26.

[32] H. L. Jiang, Y. H. Zhu, Q. Feng, Y. H. Su, X. L. Yang, C. Z. Li, Chem. A Eur. J., 2014, 20, 3106-3112.

[33] Y. M. Tan, C. F. Xu, G. X. Chen, X. L. Fang, N. F. Zheng, Q. J. Xie, Adv. Fun. Mater., 2012, 22, 4584-4591.

[34] V. Selvaraj, M. Alagar, K. S. Kumar, Appl. Catal. B, 2007, 75, 129-138.

[35] Y. Y. Jiang, Y. Z. Lu, X. D. Wang, Y. Bao, W. Chen, L. Niu, Nanoscale, 2014, 6, 15066-15072.

[36] Z. Yang, Z. Yao, G. F. Li, G. Y. Fang, H. G. Nie, Z. Liu, X. M. Zhou, X. A. Chen, S. M. Huang, ACS Nano, 2012, 6, 205-211.

[37] R. L. Liu, D. Q. Wu, X. L. Feng, K. Muellen, Angew Chem. Int. Ed., 2010, 49, 2565-2569.

\section{简便方法制备氮掺杂的碳球用作高效非金属氧还原催化剂}

童金辉, ${ }^{\mathrm{a}}$, 李文艳 ${ }^{\mathrm{a}}$, 薄丽丽 ${ }^{\mathrm{b}}$, 王文慧 ${ }^{\mathrm{a}}$, 李玉梁 ${ }^{\mathrm{a}}$, 李 涛 ${ }^{\mathrm{a}}$, 张 琦 ${ }^{\mathrm{a}}$, 范海燕,

${ }^{\mathrm{a}}$ 西北师范大学化学化工学院, 甘肃省高分子材料重点实验室, 生态环境相关高分子材料教育部重点实验室,

甘肃兰州730070, 中国

${ }^{\mathrm{b}}$ 甘肃农业大学理学院, 甘肃兰州730070, 中国

c纳扎尔巴耶夫大学科学技术学院化学系, 阿斯塔纳 010000 , 哈萨克斯坦

摘要: 随着人们环保意识的不断增强, 社会对清洁能源的需求也日益增加. 燃料电池具有效率高, 燃料来源丰富, 可直接 将化学能转化成电能且污染小等优点, 因而受到了广泛关注. 然而, 燃料电池的阴极氧还原反应(ORR)速率较慢, 成为提 高燃料电池整体效率的制约因素. 因此, 开发高性能的ORR催化剂, 加快ORR反应速率具有非常重要的意义. 目前, Pt基 催化剂被认为是活性最好的商用ORR电催化剂. 尽管此类催化剂具有较高的催化活性和良好的稳定性, 但Pt的储量有限, 
价格高昂，抗燃料毒化性能差，限制了其大规模应用.

近年来, 为了减小Pt的用量, 降低催化剂成本, 人们除了致力于研究贵金属合金催化剂及非贵金属催化剂外, 还把目 光聚焦在了非金属催化剂, 特别是碳及其复合材料的研究上. 在众多碳材料中, 碳球因具有良好的表面渗透性和较高的 机械稳定性而被广泛应用于催化、吸附、药物输送和能量存储及转化等领域中. 然而, 碳球的表面化学惰性较强, 比表面 积较低, 使其部分应用受到了限制. 因此, 人们采用了多种方法来调控碳球的物理化学性质. 其中, 向碳材料中掺入杂原 子, 尤其是氮原子的方法广受青睐. 因为杂原子的掺入会显著增强作为主体的碳原子给电子的能力和表面吸附性质, 从 而对ORR表现出优异的催化活性和稳定性.

本文以蔗糖作为碳源, 三聚氨胺作为氮源, 采用水热法及高温热解法制备了一系列氮掺杂的生物质碳球. 并对氮掺 杂量及热解温度进行了优化. 结果表明, 石墨化程度及石墨氮含量的提高, 能有效地提高催化剂的活性. 在优化了的条件 下得到的催化剂 $\mathrm{N}^{0.1} \mathrm{C}^{1.9} \mathrm{~S}-900$, 表现出了比商业 $\mathrm{Pt} / \mathrm{C}$ 催化剂更好的ORR催化性能. 在 $0.1 \mathrm{~mol} / \mathrm{L} \mathrm{KOH}$, 该催化剂催化ORR 的起始电位和半波电位分别为 -22.6 和 $-133.6 \mathrm{mV}$ (vs. Ag/AgCl), 极限电流密度为 $4.6 \mathrm{~mA} / \mathrm{cm}^{2}$, 分别比商业 $\mathrm{Pt} / \mathrm{C}$ 高出7.2 mV, $5.9 \mathrm{mV}$ 和 $0.2 \mathrm{~mA} / \mathrm{cm}^{2}$. 同时, 在经过 $30000 \mathrm{~s}$ 的稳定性测试中, $\mathrm{N}_{0.1} \mathrm{C}_{1.9} \mathrm{~S}-900$ 催化剂的电流损失也远低于 $\mathrm{Pt} / \mathrm{C}$, 表明该催化剂 具有良好的稳定性. 此外, 在抗甲醇毒化实验中, 相比于商业 $\mathrm{Pt} / \mathrm{C}, \mathrm{N}_{0.1} \mathrm{C}_{1.9} \mathrm{~S}-900$ 催化剂对甲醇有更好的耐受性. 另外, 该 催化剂催化的ORR属于高效的 $4 \mathrm{e}^{-}$途径. 可见, 该催化剂作为燃料电池的阴极氧还原反应催化剂具有广阔的前景.

关键词: 氮掺杂; 碳球; 无金属催化剂; 氧还原反应

收稿日期: 2018-04-18. 接受日期: 2018-04-23. 出版日期: 2018-06-05.

*通讯联系人. 电话: (0931)7970806; 电子信箱: jinhuitong@nwnu.edu.cn

\#通讯联系人. 电话: +7-7172-704656; 电子信箱: haiyan.fan@nu.edu.kz

基金来源：国家自然科学基金(21363021, 51302222); 长江学者和创新团队发展计划(IRT15R56).

本文的电子版全文由Elsevier出版社在ScienceDirect上出版(http://www.sciencedirect.com/science/journal/18722067). 